Heterogeneity in the Solar-Powered Consumer Electronics Market: A Discrete Choice Experiments Study

Peer-reviewed author version

LIZIN, Sebastien; VAN PASSEL, Steven \& Vranken, Liesbet (2016) Heterogeneity in the Solar-Powered Consumer Electronics Market: A Discrete Choice Experiments Study. In: Solar energy materials and solar cells, 159, p. 140-146.

DOI: 10.1016/j.solmat.2016.04.060

Handle: http://hdl.handle.net/1942/21522 
4

6

7

8

9

7

\section{Heterogeneity in the Solar-Powered Consumer Electronics Market: A Discrete Choice Experiments Study}

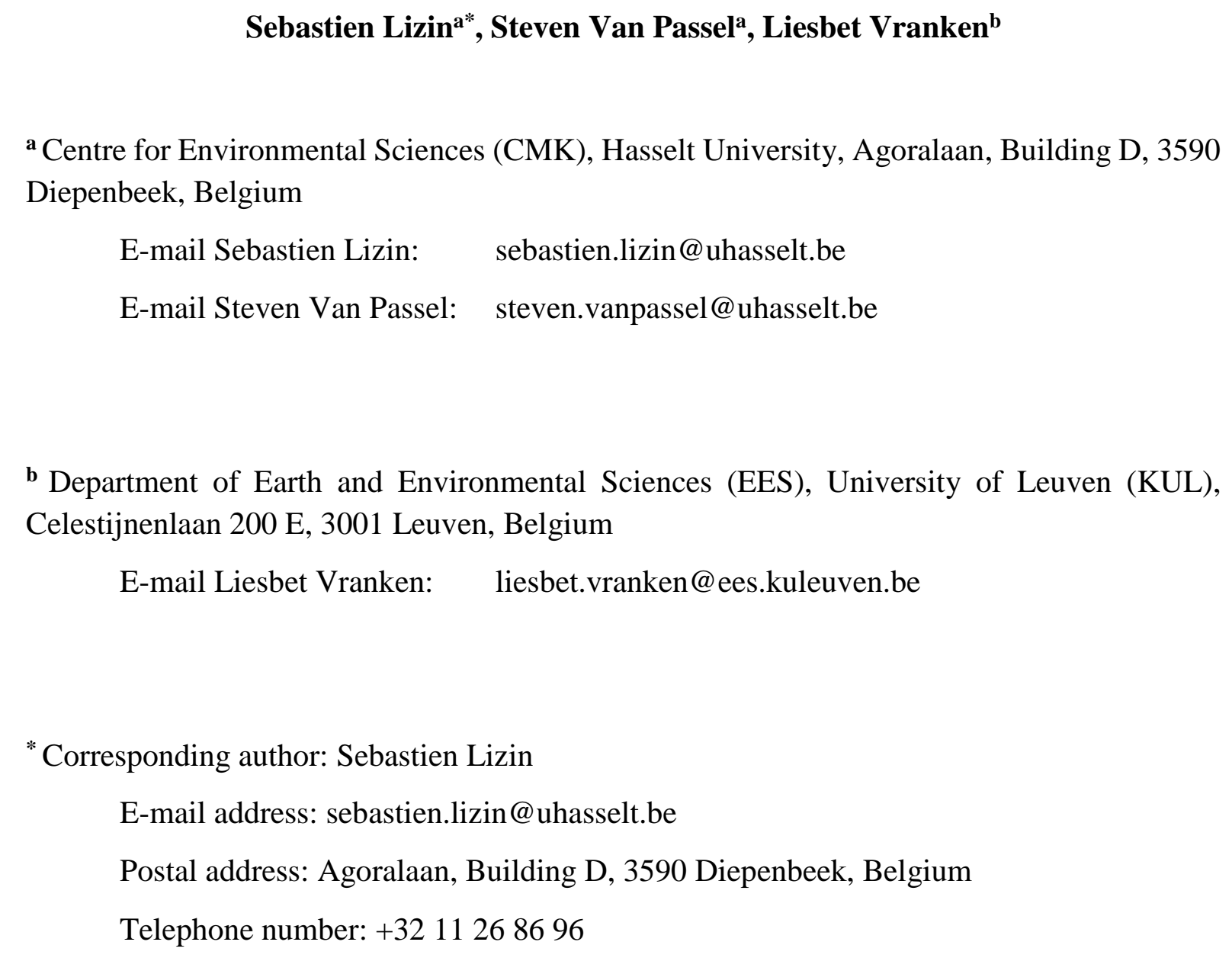

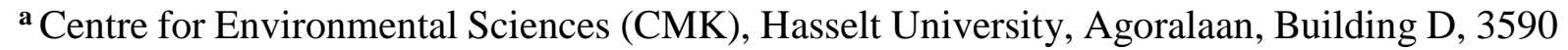

Diepenbeek, Belgium

E-mail Sebastien Lizin: sebastien.lizin@uhasselt.be

E-mail Steven Van Passel: steven.vanpassel@uhasselt.be

b Department of Earth and Environmental Sciences (EES), University of Leuven (KUL), Celestijnenlaan 200 E, 3001 Leuven, Belgium

E-mail Liesbet Vranken: liesbet.vranken@ees.kuleuven.be

*Corresponding author: Sebastien Lizin

E-mail address: sebastien.lizin@uhasselt.be

Postal address: Agoralaan, Building D, 3590 Diepenbeek, Belgium

Telephone number: +3211268696 


\section{Abstract}

23 Solar-powered consumer electronics are a likely starting point for organic photovoltaic (OPV) 24 market development. Therefore, a generic discrete choice experiments study can determine 25 how Flemish consumers value solar-cell characteristics for solar-powered consumer 26 electronics. Such characteristics include efficiency, lifetime, aesthetics, integratability, and 27 price. We contribute to the literature by investigating preference heterogeneity in a solar-power 28 niche market with an experimental design with a fixed reference alternative. The error 29 components random parameter logit (ECRPL) with interactions provides a better fit than the 30 latent class (LC) model for our choice data. The main effects had the expected signs. 31 Consequently, aesthetics and integratability are OPV's assets. Nevertheless, heterogeneity puts 32 the results that are valid for the average consumer into perspective. Based on our findings, OPV 33 commercialization efforts should target the experienced, impatient user who highly values 34 design and functionality.

36 KEYWORDS: Error Components Random Parameter Logit; Latent Class; Solar-powered 37 Consumer Electronics; Heterogeneity; OPV

\section{Highlights:}

- We investigate heterogeneous preferences for solar-powered consumer electronics.

- We present a generic DCE study with a fixed reference alternative

- The ECRPL best explains our choice data.

- Target the experienced, impatient user highly valuing design and functionality. 


\section{Introduction}

Several authors have identified solar-powered consumer electronics as a likely starting point for organic photovoltaic (OPV) solar-cells' market development (Krebs et al., 2010b, Nielsen et al., 2010). OPVs are solar cells with an all-organic, solid-state active layer (Brabec et al., 2010). Among all alternatives to crystalline silicon-based solar-cells, OPVs are considered a strong solution to the problem of high cost and low throughput (Krebs et al., 2010c). OPVs might also provide a better solution than crystalline silicon solar cells to global warming if consumers adopt this promising renewable energy technology (RET). Energy payback times (EPBTs) of only one day are predicted for OPVs under favorable circumstances, but taking lifetime issues into account. Crystalline silicon solar cells have EPBTs of one to two years (Espinosa et al., 2012).

Nevertheless, consumers' willingness to adopt a product depends on how they value it. Therefore, we performed a generic, discrete choice experiments (DCE) study to see how Flemish consumers value solar-cell characteristics for solar-powered consumer electronics. We assessed generic preferences for such solar cells by setting attribute levels to cover the range of possible levels different solar-cell types achieve. This allows for assessing the match with OPV's (future) profile. We respond to OPV material scientists' call for guidance on how to claim a significant market share of a predefined market (Krebs et al., 2010a). We contribute to existing literature by incorporating unobserved heterogeneity into our modeling efforts. To this end, we investigated preferences using the error component random parameter logit (ECRPL) and the latent class (LC) logit models.

The remainder of this paper is divided into four sections. The methodology section reviews DCE use in RET literature, explains its intuition, and describes our approach. The results section provides the sample's descriptive statistics, after which we interpret the results obtained from the different models. The conclusion summarizes our main findings.

\section{Methodology}

\subsection{DCEs covering renewable energy: A literature review}

DCEs have frequently been applied to the topic of renewable energy, albeit from different angles. Table 1 presents the results of a literature review from 2006 to 2014. Contributions mainly examine the importance of the green electricity share in the electricity mix or the valuation of socioeconomic and environmental externalities of RETs. Solar power constitutes the exception to this rule. Photovoltaics and solar water heating have been investigated with an 
eye on predicting the adoption time. Table 1 shows that solar-power niche markets have barely been investigated, with little attention toward heterogeneity. Nevertheless, Yoo and Ready (2014) showed that preferences for solar power are the most heterogeneous of all types of renewable technologies.

[Insert Table 1]

\subsection{DCEs modeling approach}

The discrete choice-based elicitation format closely resembles an actual purchasing decision (Ward et al., 2011). To formalize this decision process, DCE adopted the random utility theory (RUT), which Thurstone (1927) originally developed. McFadden (1974) translated RUT into the mathematical formulation of the conditional logit (CL) model.

The assumption of independently, identically distributed (IID) error terms allows for the convenient closed form of the CL model. The simplicity of the closed form comes at a cost, given that the CL model translates the IID assumption into substitution patterns that are restricted by the independence of irrelevant alternatives (IIA). Fully relaxing the IIA assumption without adopting different distributions for the error terms or different structures in decision-making, forces the use of mixed logit type models. Moreover, these types of models allow for unveiling unobserved heterogeneity. Mixed logit models have unconditional probabilities $P_{i j}$ equal to the integral of standard logit conditional probabilities $L_{i j}(\beta)$ over a density of parameters $f(\beta)$ (see Equation 1). This density may be continuous or discrete (Train, 2003).

An error component random parameter logit (ECRPL) model assumes a continuous distribution of attribute parameters and allows for calculating preferences at the individual level. Error components are often normally distributed as $\mathrm{N}\left(0, \sigma^{2}\right)$. The variance captures the magnitude of the correlation between the nested alternatives. Formulating the model in this way has been shown to provide the best fit when dealing with a reference alternative (Hess and Rose, 2009).

A LC model assumes a discrete distribution of attribute parameters and assesses the average preferences for homogenous segments while using a class membership function (Train, 2003).

$$
P_{i j}=\int L_{i j}(\beta) * f(\beta) * d \beta
$$




\subsubsection{Setting up DCEs}

109

110

111

112

113

114

115

116

117

118

119

120

121

122

123

124

125

126

127

128

129

130

131

132

133

134

135

136

137

138

Relevant attributes and levels were identified using focus-group discussions and expert interviews, given the lack of prior studies. A full description of the attribute development process, the motivations for the respective chosen levels, and the method for ensuring optimal understanding, can be found in Lizin et al. (2012). This process led to the conceptualization of five attributes, each consisting of four levels (see Table 2). In summary, the upper bounds for quantitative attribute levels and lower bounds for qualitative attribute levels are those for polycrystalline silicon cells. On the contrary, the lower bounds for quantitative attribute levels and upper bounds for qualitative attribute levels are values that OPV solar cells might attain. This allows for capturing all solar-cell technologies with levels between these bounds.

Based on these attributes and levels, a generic, forced choice, main-effects design for a CL was created in SAS, with a relative D-efficiency of 80.14 using zero priors by means of the alternative swapping procedure (Kuhfeld, 2010). Such a design may be reused with limited efficiency loss for estimating a random parameter logit model (Bliemer and Rose, 2010). However, statistical efficiency should not dominate respondent efficiency (Ferrini and Scarpa, 2007). Respondent efficiency is usually increased by limiting the number of attributes and levels, ensuring realism and credibility, and optimally conveying the meaning of attributes.

We felt the need to go further for our case study. Focus-group discussions revealed that most people are knowledgeable of solar cells' application in solar panels, which are generally made of polycrystalline silicon. However, most people are unaware of the different types of PV solar cells used in alternative applications. To deal with respondents' limited experience polycrystalline silicon levels serve as a point of reference by means of a fixed reference alternative. In theory, such an alternative can represent an opt-out option (Kontoleon and Yabe, 2003). In our case, as respondents were largely unaware of which type of solar cell they possessed, the constant alternative does not represent an opt-out nor even a perceived status quo (Domínguez-Torreiro and Soliño, 2011). Neither does it provide a reference alternative, as this would also require respondent awareness. The fixed alternative merely serves to provide a contextual reference (Schläpfer and Fischhoff, 2012). Respondents were consequently forced to choose between the provided alternatives. Hence, the results are meaningful for people having decided they want to buy a solar-powered consumer electronics device. This led to a design consisting of 16 choice sets, each presenting four alternatives. Given the large number 
of choice sets, we decided to block the design over two surveys. To counter for order effects bias, the choice sets' order was randomized 10 times for both survey versions.

\subsubsection{Questionnaire development, conduct and processing}

143 We developed a questionnaire based on Bateman et al.'s (2002) guidelines. Accordingly, we 144 divided it into four sections: The survey's purpose; attitudinal questions and use of the device;

145 the choice sets; and socio-demographic questions. Prior to the final roll-out, the questionnaire 146 was pilot-tested on a group of 30 respondents to verify language understanding.

147 After modifications, the actual survey was conducted on various intercity train travels throughout the entire Flemish region during the 2011 and 2012 summer holiday periods. This ensured the presence of many (about 53 percent) infrequent train users. However, there still may have been an eco-friendly bias because people unwilling to use the train were left out.

This type of sampling can be classified as intercept sampling. Additionally, quota screening was used to closely resemble the 2010 gender distribution (49.35 percent male) obtained when using probability sampling. Motivated by solar cells' technical nature and the intrinsic cognitive burden on respondents associated with DCEs, the target population was limited to anyone between the ages of 18 and 64 living in the Flemish region who understood the native language. We assumed that anybody in this age group at a given point in time would buy a solar-powered consumer electronics device. A simple pen-and-paper distribution method was used for taking the survey, with additional guidance from trained surveyors. The surveyors' ability to help people through the process in a personalized way was crucial in making this decision (Arrow et al., 1993). Task familiarity was further augmented by providing a written, filled-in choice set example. In total, 450 fully filled-in questionnaires were collected.

\subsubsection{Econometric analysis}

163 The first step in the econometric analysis of the DCE data was to identify the most qualified expression for the indirect utility function, without and with interaction effects. This was done using the CL model. All tested attributes demonstrated at least one significantly different slope. The price attribute was coded linearly to allow straightforward calculations of willingness to pay. Dummy coding was used because of ease of interpretation, relative to effects coding. 
omitted base levels. Consequently, the direct utility $V_{i j}$ was defined in Equation 2 with abbreviated subscripts for the respective estimated parameters (see Table 2).

173 Socio-economic variables can only be included as interaction terms because they are constant across choice occasions for any individual (Hanley et al., 2001). In that case, $V_{i j}$ takes the form shown in Equation 3, with $\left(S_{Z} * X_{q}\right)$ as the interaction effects and $\beta_{\#}$ as the interaction effects' parameter weights. The identified interaction effects are: High energy awareness $\left(S_{\text {energyaware }}\right)$; high environmental awareness ( $\left.S_{\text {envaware }}\right)$; high impatience $\left(S_{\text {impatient }}\right)$; and high experience with PV application ( $S_{\text {experienced }}$ ). Energy awareness was measured as an index consisting of questions measuring energy-saving behavior. Environmental awareness was measured as an index consisting of questions gauging pro-environmental behavior. Impatience was measured on a single Likert scale assessing how inconvenient respondents think it is to charge electrical devices. Those who considered charging very inconvenient were considered impatient users. The output of the final models is discussed in the results section.

$V_{i j}=\beta_{p r} X_{p r}+\beta_{15 y} X_{15 y}+\beta_{10 y} X_{10 y}+\beta_{5 y} X_{5 y}+\beta_{15 \%} X_{15 \%}+\beta_{10 \%} X_{10 \%}+\beta_{5 \%} X_{5 \%}+$

\section{Results}

\subsection{Descriptive statistics}

Table 3 shows the descriptive statistics. We were dealing with a younger, moderately environmentally aware, fairly energy-aware audience. Only 6.73 percent had not taken action to lower their energy bill, and 86.55 percent had used solar-powered consumer electronics, mainly solar-powered calculators in the past. This comes as no surprise, as calculators were the first solar-powered consumer product (Apostolou and Reinders, 2014).

Furthermore, respondents were divided concerning the inconvenience of having to charge their electronic devices. Using a five-point Likert scale (ranging from -2 to 2), we found that 40 percent found charging to be inconvenient, another 40 percent thought it not bothersome, and 20 percent were neutral. The respondents were also asked to motivate their response. The first group's most frequently found motivations were: They did not like having to monitor the 
battery's status, so often forgot to recharge; no outlet or charger compatible to the device was available; and the full freedom of operation was lost while charging. The second group's most popular answers were: It is a habit; and it does not require much effort.

Household size, family income, and educational level were three potential predictor variables for domestic energy use (Sardianou, 2007). Their respective means and distributions are also provided. For completeness, we also present the respondents' geographic distribution (within Flanders).

\section{[Insert Table 3]}

\subsection{Parameter estimates}

Table 4 presents the results of the final ECRPL with interactions. Models were run using 1,000 Halton draws, assuming normal distributions for random parameters and accounting for correlation between random parameters. The suitability of this distributional assumption was verified using kernel density estimation (Hensher and Greene, 2003).

All attributes were significant factors in determining consumers' choice. Furthermore, all main effect coefficients showed the expected a priori signs for the average consumer. More specifically, the average respondent preferred a solar cell with the highest efficiency, the highest lifetime, the nicest aesthetics, and a decent integratability at the lowest price.

Observed heterogeneity was captured by creating interaction effects with socio-demographic characteristics (SDCs). Their signs and values put the results, which were valid for the mean main effect coefficients, into perspective. On the one hand, the highly environmentally aware respondents had an aversion for better-looking products. Perhaps they associated better appearances with higher environmental burdens. Similarly, the experienced user did not show a strong dislike for five-year lifetimes. On the other hand, the highly energy-aware individuals showed a stronger than average dislike for low efficiencies, while the impatient user was also more sensitive to aesthetically pleasing products. In spite of the various significant interactions, all main effects showed significant unobserved heterogeneity in the ECRPL model. Most heterogeneity was found for the attribute levels that were most likely for OPVs; in other words. for cells with an efficiency of 5 percent and a lifetime of five years. Finally, a significant shared error component was found to be highly significant, confirming cross-correlation between the hypothetical alternatives.

[Insert Table 4] 
In the LC model, respondents were divided into homogenous segments based on SDCs and the highest class decision rule. Following Birol et al. (2006), we assumed that the respondent characteristics used to obtain significant interactions most affected segment membership. In order to choose the most suitable number of segments, information criteria were investigated while increasing the number of segments. The lower the value of the BIC and the Bozgodan AIC (AIC3) (Andrews and Currim, 2003), the better the model fit. In our case, both criteria pointed to the same conclusion. Consequently, a model with four segments was considered optimal. The results of the LC model are provided in Table 5.

From the results, respondents belonging to classes 1 to 4 were best characterized by: (1) a high sensitivity toward nicer aesthetics; (2)

(2) high preference for good integratability; (3) high aversion for low efficiencies and high prices; and (4) great dislike for low lifetimes and efficiencies. Additionally, the fourth segment was not influenced in their choice by the price, and segments 2 and 3 seem to be heterogeneous in their preferences for lifetime levels. The second part of the table reports the segment membership coefficients relative to the normalized fourth segment. Only high environmental awareness and impatience dummies were significant segmenting variables for the first segment.

To compare the ECRPL and LC model fit, we used a test Ben-Akiva and Swait (1986) suggested, given that we are no longer working with nested models. The test confirms that the more parsimonious ECRPL is the best-fitting model. The information criteria point to a similar conclusion.

\subsection{WTP estimates}

Since ECRPL is the best-fitting model, we used it to compute the welfare measures. WTP estimates were calculated at the means, using the Delta method, while correcting for the interactions with SDCs. Table 6 shows the results of the estimations. WTP measures reveal how much people are willing to pay for a change from the base level to the displayed attribute level. The WTP measures are given as $€ / W p$. For instance, the WTP estimate for a lifetime of five years indicates that the average respondent should be compensated by $10.33 € / \mathrm{Wp}$ for a loss in lifetime of 15 years. Additionally, kernel density plots showing WTP estimate distributions reconfirm that the widest WTP distributions were found for the attribute levels most likely for OPV, i.e. cells with an efficiency of 5 percent and a lifetime of five years. 


\section{Conclusion and discussion}

264 Discrete choice experiments (DCEs) have been widely applied to assess the importance of the green electricity share in the electricity mix or the valuation of socioeconomic and environmental externalities. Solar-power niche markets have barely been investigated, or with little attention to heterogeneity. Nevertheless, Yoo and Ready (2014) showed that preferences for solar power are more heterogeneous than preferences for all other types of renewable technologies. Moreover, by investigating preferences for solar-powered consumer electronics, we answered OPV material scientists' call for guidance on how to gain market share (Krebs et al., 2010a).

To fill these gaps, we investigated Flemish consumer preferences for solar-powered consumer electronics by using generic DCEs with a fixed reference alternative representing a polycrystalline silicon solar cell. This alternative was included in the experimental design to provide the respondents with a reference frame. Focus-group discussions showed that respondents were largely unfamiliar with PV cell types and performances, but used solar panels (which are mostly of the polycrystalline silicon type) as a point of reference.

278 We estimated preferences using the error component random parameter logit (ECRPL) model (which was well-suited to deal with fixed reference alternatives), and the latent class (LC) model. A test Ben-Akiva and Swait suggested, confirmed that the ECRPL model with interactions provided a better fit than the LC model for our choice data. Mean main effects exhibited the expected signs for the efficiency dummies (-), lifetime dummies (-), aesthetics dummies (+), integratability dummies (+), and price (-). Hence, aesthetics and integratability should be seen as OPV assets.

285 However, the mean main effect coefficients should be interpreted with caution, as our analysis indicates that preferences are very heterogeneous. Respondents with specific characteristics had inverse preferences. In particular, respondents with high environmental awareness attached less importance to better-looking products. Furthermore, experienced users liked lifetimes of five years more than others. Alternatively, the main effects were reinforced for some type of respondents. Those with high energy awareness typically had a higher preference for low efficiencies than respondents with moderate or low levels of energy awareness. Impatient respondents, who strongly disliked waiting while their device charged, also had stronger preferences for good-looking products compared to more patient respondents. Therefore, we 
concur with Apostolou and Reinders (2014) in stating that functionality depends on the user's charging habits.

296 Based on our findings, we would advise organic photovoltaic (OPV) commercialization efforts

297 to aim for the experienced, impatient user who highly values a functional design. Moreover, 298 the ECRPL also allowed us to grasp unobserved heterogeneity by estimating the standard 299 deviations of the normally distributed parameters. All random parameters showed significant 300 unobserved heterogeneity, in spite of the various significant interactions with socio301 demographic characteristics. Moreover, the magnitude shows that the most heterogeneity was

302

303

304

305

306

307

308

309

310

311

312

313

314

315

316

317

318

319

320

321

322

323

324 present in the attribute levels likely for OPV in its early development stages; in other words, cells with an efficiency of 5 percent and a lifetime of five years. This may point to a segment of consumers that perceives lower requirements for consumer electronics to be satisfactory, signaling the viability of an OPV-powered consumer electronics niche market. We finish with a word of caution that these are exploratory results that should be reconfirmed by probabilistic sampling.

\section{Acknowledgements}

Sebastien Lizin thanks the Research Foundation Flanders (FWO) for funding his postdoctoral mandate with grant number $12 \mathrm{G} 5415 \mathrm{~N}$, without which it would have been impossible to revise this work.

\section{References}

Amador, F. J., Gonzalez, R. M. and Ramos-Real, F. J. (2013). "Supplier choice and WTP for electricity attributes in an emerging market: The role of perceived past experience, environmental concern and energy saving behavior." Energy Economics 40: 953-966. DOI: 10.1016/j.eneco.2013.06.007.

Andrews, R. and Currim, I. (2003). "A Comparison of Segment Retention Criteria for Finite Mixture Logit Models." Journal of Marketing Research 40(2): 235-243. DOI: 10.1509/jmkr.40.2.235.19225.

Apostolou, G. and Reinders, A. H. M. E. (2014). "Overview of Design Issues in ProductIntegrated Photovoltaics." Energy Technology 2(3): 229-242. DOI: 10.1002/ente.201300158.

Arrow, K., Solow, R., Portney, P., Leamer, E., Radner, R. and Schuman, H. (1993). "Report of the NOAA Panel on contingent valuation." Federal Register 58(10): 4601-4614.

Bateman, I., Carson, R., Day, B., Hanemann, M., Hanley, N., Hett, T., Jones-Lee, M., Loomes, G., Mourato, S., Özdemiroglu, E., Pearce, D., Sugden, R. and Swanson, J. (2002). Economic valuation with stated preference techniques: A manual. Cheltenham, Edward Elgar.

Ben-Akiva, M. and Swait, J. (1986). "The Akaike Likelihood Ratio Index." Transportation Science 20(2): 133-136. DOI: 10.2307/25768218. 
Bergmann, A., Colombo, S. and Hanley, N. (2008). "Rural versus urban preferences for renewable energy developments." Ecological Economics 65(3): 616-625. DOI: 10.1016/j.ecolecon.2007.08.011.

332 Bergmann, A., Hanley, N. and Wright, R. (2006). "Valuing the attributes of renewable energy investments." Energy Policy 34(9): 1004-1014. DOI: DOI: 10.1016/j.enpol.2004.08.035.

Birol, E., Karousakis, K. and Koundouri, P. (2006). "Using a choice experiment to account for preference heterogeneity in wetland attributes: The case of Cheimaditida wetland in Greece." Ecological Economics 60(1): 145-156. DOI: 10.1016/j.ecolecon.2006.06.002.

Bliemer, M. and Rose, J. (2010). "Construction of experimental designs for mixed logit models allowing for correlation across choice observations." Transportation Research Part B: Methodological 44(6): 720-734. DOI: 10.1016/j.trb.2009.12.004.

340 Borchers, A., Duke, J. and Parsons, G. (2007). "Does willingness to pay for green energy differ by source?" Energy Policy 35(6): 3327-3334. DOI: DOI: 10.1016/j.enpol.2006.12.009.

342 Brabec, C. J. (2004). "Organic photovoltaics: technology and market." Solar Energy Materials and Solar Cells 83(2-3): 273-292. DOI: http://dx.doi.org/10.1016/j.solmat.2004.02.030. 3856. DOI: 10.1002/adma.200903697.

347 Cicia, G., Cembalo, L., Del Giudice, T. and Palladino, A. (2012). "Fossil energy versus nuclear, wind, solar and agricultural biomass: Insights from an Italian national survey." Energy Policy 42: 59-66. DOI: 10.1016/j.enpol.2011.11.030.

350 Domínguez-Torreiro, M. and Soliño, M. (2011). "Provided and perceived status quo in choice experiments: Implications for valuing the outputs of multifunctional rural areas." Ecological Economics 70(12): 2523-2531. DOI: 10.1016/j.ecolecon.2011.08.021.

353 Drechsler, M., Ohl, C., Meyerhoff, J., Eichhorn, M. and Monsees, J. (2011). "Combining 354 spatial modeling and choice experiments for the optimal spatial allocation of wind turbines." 355 Energy Policy 39(6): 3845-3854. DOI: 10.1016/j.enpol.2011.04.015.

356 Ek, K. and Persson, L. (2014). "Wind farms - Where and how to place them? A choice experiment approach to measure consumer preferences for characteristics of wind farm establishments in Sweden." Ecological Economics 105: 193-203. DOI: 10.1016/j.ecolecon.2014.06.001.

360 El Chaar, L., Lamont, L. and El Zein, N. (2011). "Review of photovoltaic technologies." 361 Renewable and Sustainable Energy Reviews 15(5): 2165-2175. DOI: 362 10.1016/j.rser.2011.01.004.

363 Espinosa, N., Hosel, M., Angmo, D. and Krebs, F. C. (2012). "Solar cells with one-day energy 364 payback for the factories of the future." Energy \& Environmental Science 5(1): 5117-5132.

365 Ferrini, S. and Scarpa, R. (2007). "Designs with a priori information for nonmarket valuation 366 with choice experiments: A Monte Carlo study." Journal of Environmental Economics and 367 Management 53(3): 342-363. DOI: DOI: 10.1016/j.jeem.2006.10.007. 

with higher electricity prices? Evidence from a Spanish region." Energy Policy 50: 784-794. DOI: 10.1016/j.enpol.2012.08.028.

371 Han, S.-Y., Kwak, S.-J. and Yoo, S.-H. (2008). "Valuing environmental impacts of large dam 372 construction in Korea: An application of choice experiments." Environmental Impact 373 Assessment Review 28(4-5): 256-266. DOI: 10.1016/j.eiar.2007.07.001.

374 Hanley, N., Mourato, S. and Wright, R. (2001). "Choice Modelling Approaches: A Superior Alternative for Environmental Valuatioin?" Journal of Economic Surveys 15(3): 435-462. DOI: 10.1111/1467-6419.00145.

377 Hensher, D. and Greene, W. (2003). "The Mixed Logit model: The state of practice." 378 Transportation 30(2): 133-176. DOI: 10.1023/a:1022558715350.

379 Hess, S. and Rose, J. (2009). "Should Reference Alternatives in Pivot Design SC Surveys be 380 Treated Differently?" Environmental and Resource Economics 42(3): 297-317. DOI: 10.1007/s10640-008-9244-6.

382 Islam, T. (2014). "Household level innovation diffusion model of photo-voltaic (PV) solar cells from stated preference data." Energy Policy 65: 340-350. DOI: 10.1016/j.enpol.2013.10.004.

Islam, T. and Meade, N. (2013). "The impact of attribute preferences on adoption timing: The case of photo-voltaic (PV) solar cells for household electricity generation." Energy Policy 55: 521-530. DOI: 10.1016/j.enpol.2012.12.041.

Jensen, K., Clark, C., English, B., Menard, R., Skahan, D. and Marra, A. (2010). "Willingness to pay for E85 from corn, switchgrass, and wood residues." Energy Economics 32(6): 12531262. DOI: 10.1016/j.eneco.2010.06.002.

Jørgensen, M., Norrman, K. and Krebs, F. (2008). "Stability/degradation of polymer solar cells." Solar Energy Materials and Solar Cells 92(7): 686-714. DOI: DOI: 10.1016/j.solmat.2008.01.005.

393

394

395

396

397

398

399

400

401

402

403

404

405

406

407

Kaenzig, J., Heinzle, S. L. and Wustenhagen, R. (2013). "Whatever the customer wants, the customer gets? Exploring the gap between consumer preferences and default electricity products in Germany." Energy Policy 53: 311-322. DOI: 10.1016/j.enpol.2012.10.061.

Kataria, M. (2009). "Willingness to pay for environmental improvements in hydropower regulated rivers." Energy Economics 31(1): 69-76. DOI: 10.1016/j.eneco.2008.07.005.

Kontoleon, A. and Yabe, M. (2003). "Assessing the impacts of alternative 'opt-out' formats in choice experiment studies: consumer preferences for genetically modified content and production information in food." Journal of Agricultural Policy Research 5: 1-43.

Kosenius, A. K. and Ollikainen, M. (2013). "Valuation of environmental and societal tradeoffs of renewable energy sources." Energy Policy 62: 1148-1156. DOI: 10.1016/j.enpol.2013.07.020.

Krebs, F., Fyenbo, J. and Jorgensen, M. (2010a). "Product integration of compact roll-to-roll processed polymer solar cell modules: methods and manufacture using flexographic printing, slot-die coating and rotary screen printing." Journal of Materials Chemistry 20(41): 8994-9001. DOI: 10.1039/c0jm01178a. 
408 Krebs, F. C., Nielsen, T. D., Fyenbo, J., Wadstrom, M. and Pedersen, M. S. (2010b).

409 "Manufacture, integration and demonstration of polymer solar cells in a lamp for the "Lighting

410 Africa" initiative." Energy \& Environmental Science 3(5): 512-525.

411 Krebs, F. C., Tromholt, T. and Jorgensen, M. (2010c). "Upscaling of polymer solar cell 412 fabrication using full roll-to-roll processing." Nanoscale 2(6): 873-886.

$413 \mathrm{Ku}$, S.-J. and Yoo, S.-H. (2010). "Willingness to pay for renewable energy investment in Korea: 414 A choice experiment study." Renewable and Sustainable Energy Reviews 14(8): 2196-2201. 415 DOI: 10.1016/j.rser.2010.03.013.

416 Kuhfeld, W. (2010). "Marketing Research Methods in SAS: Experimental Design, Choice, 417 Conjoint, and Graphical Techniques." Cary: 1309.

418 Lee, J.-S. and Yoo, S.-H. (2009). "Measuring the environmental costs of tidal power plant 419 construction: A choice experiment study." Energy Policy 37(12): 5069-5074. DOI: $420 \quad 10.1016 /$ j.enpol.2009.07.015.

421 Lizin, S., Van Passel, S., De Schepper, E. and Vranken, L. (2012). "The future of organic 422 photovoltaic solar cells as a direct power source for consumer electronics." Solar Energy 423 Materials and Solar Cells 103: 1-10. DOI: 10.1016/j.solmat.2012.04.001.

424 Longo, A., Markandya, A. and Petrucci, M. (2008). "The internalization of externalities in the 425 production of electricity: Willingness to pay for the attributes of a policy for renewable energy." 426 Ecological Economics 67(1): 140-152. DOI: 10.1016/j.ecolecon.2007.12.006.

427 McFadden, D. (1974). Conditional logit analysis of qualitative choice behaviour. Frontiers in 428 Econometrics. P. Zarembka. New York, Academic Press: 105-142.

429 Meyerhoff, J., Ohl, C. and Hartje, V. (2010). "Landscape externalities from onshore wind 430 power." Energy Policy 38(1): 82-92. DOI: 10.1016/j.enpol.2009.08.055.

431 Nielsen, T. D., Cruickshank, C., Foged, S., Thorsen, J. and Krebs, F. C. (2010). "Business, 432 market and intellectual property analysis of polymer solar cells." Solar Energy Materials and 433 Solar Cells 94(10): 1553-1571. DOI: http://dx.doi.org/10.1016/j.solmat.2010.04.074.

434 Sardianou, E. (2007). "Estimating energy conservation patterns of Greek households." Energy 435 Policy 35(7): 3778-3791. DOI: 10.1016/j.enpol.2007.01.020.

436 Scarpa, R. and Willis, K. (2010). "Willingness-to-pay for renewable energy: Primary and discretionary choice of British households' for micro-generation technologies." Energy Economics 32(1): 129-136. DOI: DOI: 10.1016/j.eneco.2009.06.004.

Schläpfer, F. and Fischhoff, B. (2012). "Task familiarity and contextual cues predict hypothetical bias in a meta-analysis of stated preference studies." Ecological Economics 81: 44-47. DOI: 10.1016/j.ecolecon.2012.06.016.

442 Soliño, M. (2010). "External benefits of biomass-e in Spain: An economic valuation." 443 Bioresource Technology 101(6): 1992-1997. DOI: 10.1016/j.biortech.2009.09.086.

444 Strazzera, E., Mura, M. and Contu, D. (2012). "Combining choice experiments with 445 psychometric scales to assess the social acceptability of wind energy projects: A latent class 446 approach." Energy Policy 48: 334-347. DOI: 10.1016/j.enpol.2012.05.037. 
447 Susaeta, A., Lal, P., Alavalapati, J. and Mercer, E. (2011). "Random preferences towards

448 bioenergy environmental externalities: A case study of woody biomass based electricity in the

449 Southern United States." Energy Economics 33(6): 1111-1118. DOI:

450 10.1016/j.eneco.2011.05.015.

451 Tabi, A., Hille, S. L. and Wuestenhagen, R. (2014). "What makes people seal the green power

452 deal? - Customer segmentation based on choice experiment in Germany." Ecological

453 Economics 107: 206-215. DOI: 10.1016/j.ecolecon.2014.09.004.

454 Thurstone, L. (1927). "A law of comparative judgment." Psychological Review 34: 273-286.

455 Train, K. (2003). Discrete choice methods with simulation. Cambrigde, Cambridge University 456 Press.

457 Vazquez, A. and Iglesias, G. (2015). "Public perceptions and externalities in tidal stream 458 energy: A valuation for policy making." Ocean \& Coastal Management 105: 15-24. DOI: 459 10.1016/j.ocecoaman.2014.12.017.

460 Ward, D., Clark, C., Jensen, K. and Yen, S. (2011). "Consumer willingness to pay for 461 appliances produced by Green Power Partners." Energy Economics 33(6): 1095-1102. DOI: 462 10.1016/j.eneco.2011.02.003.

463 Willis, K., Scarpa, R., Gilroy, R. and Hamza, N. (2011). "Renewable energy adoption in an 464 ageing population: Heterogeneity in preferences for micro-generation technology adoption." 465 Energy Policy 39(10): 6021-6029. DOI: 10.1016/j.enpol.2011.06.066.

466 Yamaguchi, Y., Akai, K., Shen, J. Y., Fujimura, N., Shimoda, Y. and Saijo, T. (2013).

467 "Prediction of photovoltaic and solar water heater diffusion and evaluation of promotion 468 policies on the basis of consumers' choices." Applied Energy 102: 1148-1159. DOI: 469 10.1016/j.apenergy.2012.06.037.

470 Yoo, J. and Ready, R. C. (2014). "Preference heterogeneity for renewable energy technology." 471 Energy Economics 42: 101-114. DOI: 10.1016/j.eneco.2013.12.007. 
475 Table 1: Discrete choice experiments eliciting consumers' valuation of (the effects of) renewable energy

\begin{tabular}{|c|c|c|c|c|}
\hline RES & Reference & Topic & $\begin{array}{l}\text { Observed } \\
\text { heterogeneity }\end{array}$ & $\begin{array}{l}\text { Unobserved } \\
\text { heterogeneity }\end{array}$ \\
\hline Biomass & Jensen et al. (2010) & $\begin{array}{l}\text { Valuation of E85 fuel originating from } \\
\text { different biomass types }\end{array}$ & $\mathrm{X}$ & RPL \\
\hline Biomass & Soliño (2010) & $\begin{array}{l}\text { Valuation of a forest biomass promotion } \\
\text { program }\end{array}$ & $\mathrm{X}$ & l \\
\hline Biomass & Susaeta et al. (2011) & $\begin{array}{l}\text { Valuation of woody biomass' positive } \\
\text { externalities }\end{array}$ & $\mathrm{X}$ & RPL \\
\hline Hydro & Han et al. (2008) & $\begin{array}{l}\text { Valuation of environmental impacts of } \\
\text { large dam construction }\end{array}$ & $\mathrm{X}$ & l \\
\hline Hydro & Kataria (2009) & $\begin{array}{l}\text { Valuation of environmental improvements } \\
\text { for hydropower regulated rivers }\end{array}$ & $\mathrm{X}$ & RPL \\
\hline Solar & $\begin{array}{l}\text { Islam and Meade } \\
\text { (2013) }\end{array}$ & $\begin{array}{l}\text { Estimation of preferences for factors } \\
\text { influencing solar panel adoption }\end{array}$ & l & GMXL \\
\hline Solar & (Islam, 2014) & $\begin{array}{l}\text { Estimation of preferences for factors } \\
\text { influencing solar panel adoption }\end{array}$ & l & $\mathrm{LC}$ \\
\hline Solar & Lizin et al. (2012) & $\begin{array}{l}\text { Valuation of solar cell characteristics for } \\
\text { powering consumer electronics }\end{array}$ & $\mathrm{X}$ & l \\
\hline Solar & $\begin{array}{l}\text { Yamaguchi et al. } \\
\text { (2013) }\end{array}$ & $\begin{array}{l}\text { Estimation of preferences for factors } \\
\text { influencing solar panel and solar hot water } \\
\text { adoption }\end{array}$ & l & l \\
\hline Tidal & Lee and Yoo (2009) & $\begin{array}{l}\text { Valuation of environmental damage caused } \\
\text { by the construction of a tidal power plant }\end{array}$ & l & l \\
\hline Tidal & $\begin{array}{l}\text { Vazquez and Iglesias } \\
\text { (2015) }\end{array}$ & $\begin{array}{l}\text { Valuation of environmental and socio- } \\
\text { economic externalities of a tidal power } \\
\text { plant }\end{array}$ & $\mathrm{X}$ & l \\
\hline Wind & $\begin{array}{l}\text { Drechsler et al. } \\
\text { (2011) }\end{array}$ & Optimal spatial allocation of wind turbines & l & l \\
\hline Wind & $\begin{array}{l}\text { Ek and Persson } \\
\text { (2014) }\end{array}$ & Optimal establishment of wind farms & $\mathrm{X}$ & RPL\&LC \\
\hline Wind & $\begin{array}{l}\text { Meyerhoff et al. } \\
\text { (2010) }\end{array}$ & $\begin{array}{l}\text { Valuation of landscape externalities of } \\
\text { onshore wind turbines }\end{array}$ & $\mathrm{X}$ & $\mathrm{LC}$ \\
\hline Wind & Strazzera et al. (2012) & Social acceptability of wind turbines & $\mathrm{X}$ & $\mathrm{LC}$ \\
\hline Mix & Amador et al. (2013) & $\begin{array}{l}\text { The influence on WTP of the renewable } \\
\text { energy share in the electricity mix }\end{array}$ & & \\
\hline Mix & $\begin{array}{l}\text { Bergmann et al. } \\
\text { (2006) }\end{array}$ & $\begin{array}{l}\text { Preferences over environmental and } \\
\text { employment impacts that may result from } \\
\text { renewable energy projects }\end{array}$ & $\mathrm{X}$ & l \\
\hline Mix & $\begin{array}{l}\text { Bergmann et al. } \\
\text { (2008) }\end{array}$ & $\begin{array}{l}\text { Valuation of environmental and } \\
\text { employment impacts that may result from } \\
\text { renewable energy projects }\end{array}$ & $\mathrm{X}$ & RPL \\
\hline Mix & Borchers et al. (2007) & $\begin{array}{l}\text { The influence on WTP of the specific } \\
\text { energy source of origin }\end{array}$ & $\mathrm{X}$ & NL \\
\hline
\end{tabular}




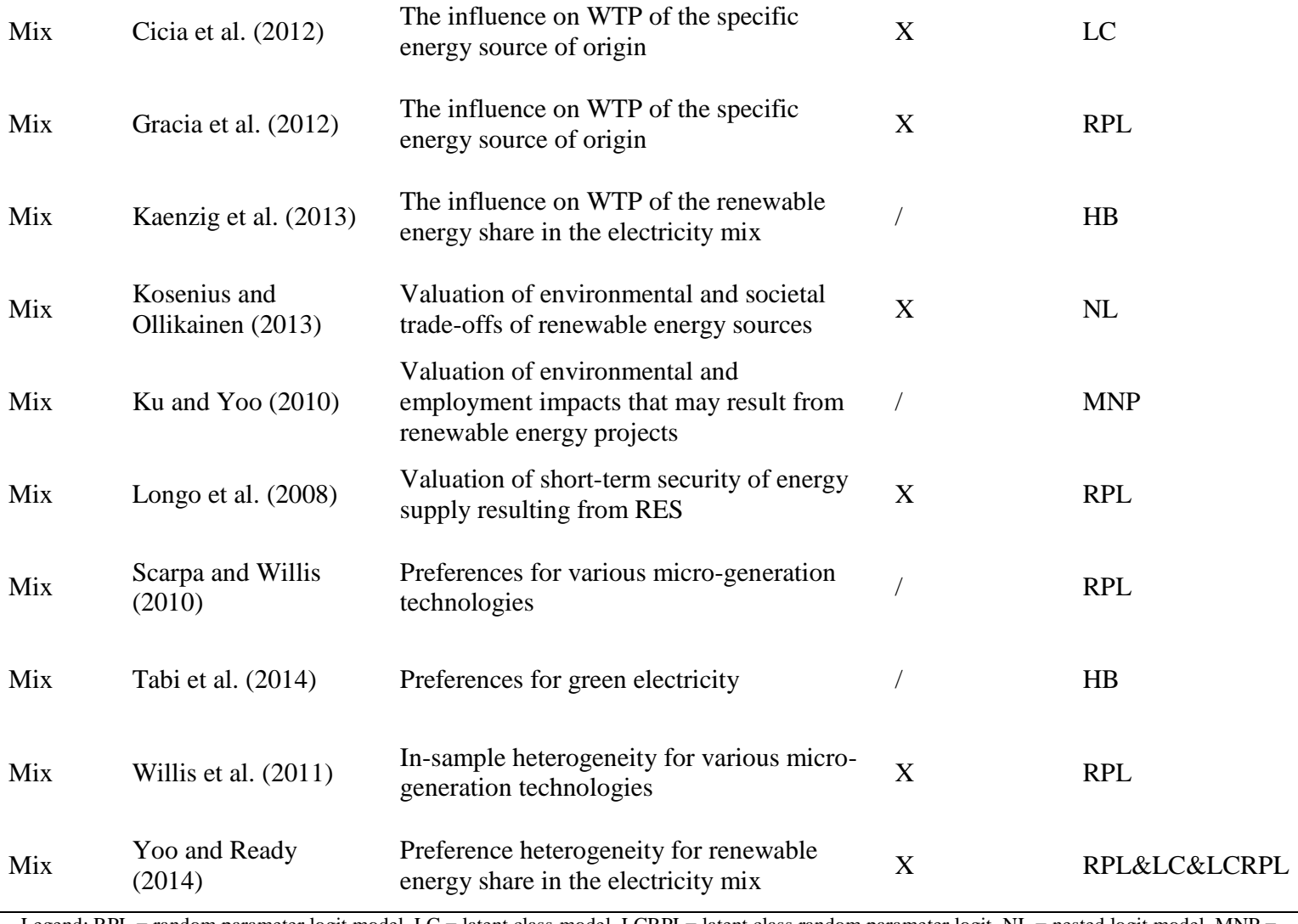

Legend: $\mathrm{RPL}=$ random parameter logit model, $\mathrm{LC}=$ latent class model, $\mathrm{LCRPL}=$ latent class random parameter logit, $\mathrm{NL}=$ nested logit model, $\mathrm{MNP}=$ multinomial probit model, GMXL = generalized mixed logit; HB= hierarchical Bayes model $/=$ type of heterogeneity remained untreated, $\mathrm{X}=$ observed 


\begin{tabular}{|c|c|c|c|c|}
\hline Attribute & Meaning & Levels & $\begin{array}{l}\text { Estimated } \\
\text { parameters }\end{array}$ & Base level \\
\hline Price & $\begin{array}{l}\text { The selling price of fully integrated solar cells is } \\
\text { commonly expressed in terms of Euro/Watt peak } \\
(€ / \mathrm{Wp}) \text {. The } \mathrm{Wp} \text { is an industry-wide agreed-upon unit } \\
\text { of power, which is found by measuring the power } \\
\text { output under standard testing conditions (El Chaar et } \\
\text { al., 2011). }\end{array}$ & $\begin{array}{l}3.5,2.5,1.5 \text {, and } 0.5 \\
€ / \mathrm{Wp}\end{array}$ & $\beta_{p r}$ & / \\
\hline Efficiency & $\begin{array}{l}\text { Fully integrated solar cells' efficiency equals the } \\
\text { percentage of sunlight reaching a solar cell that is } \\
\text { converted to electricity under standard testing } \\
\text { conditions (Brabec, 2004). }\end{array}$ & $\begin{array}{l}20,15,10 \text {, and } 5 \\
\text { percent }\end{array}$ & $\begin{array}{l}\beta_{15 \%}, \beta_{10 \%} \\
\beta_{5 \%}\end{array}$ & $\beta_{20 \%}$ \\
\hline Lifetime & $\begin{array}{l}\text { Fully integrated solar cells' lifetime is defined as the } \\
\text { period of time during which the cells maintain at least } \\
80 \text { percent of their initial efficiency (Jørgensen et al., } \\
2008 \text { ). }\end{array}$ & $\begin{array}{l}20,15,10, \text { and } 5 \\
\text { years }\end{array}$ & $\begin{array}{c}\beta_{15 y}, \beta_{10 y} \\
\beta_{5 y}\end{array}$ & $\beta_{20 y}$ \\
\hline Aesthetics & $\begin{array}{l}\text { Aesthetics is defined as a measure of how appealing } \\
\text { a product is to the eye. }\end{array}$ & $\begin{array}{l}\text { very ugly, ugly, nice, } \\
\text { and very nice }\end{array}$ & $\begin{array}{c}\beta_{u g}, \beta_{n i} \\
\beta_{v n i}\end{array}$ & $\beta_{v u g}$ \\
\hline Integratability & $\begin{array}{l}\text { Integratability is defined as how easily solar cells can } \\
\text { be integrated into any consumer electronics product. } \\
\text { It is an overarching attribute, taking into account } \\
\text { weight, thickness and flexibility, and serves as a } \\
\text { proxy for functionality. }\end{array}$ & $\begin{array}{l}\text { hardly integratable, } \\
\text { poorly integratable, } \\
\text { integratable, and very } \\
\text { integratable }\end{array}$ & $\begin{array}{c}\beta_{\text {pint }}, \beta_{\text {int }} \\
\beta_{\text {vint }}\end{array}$ & $\beta_{\text {hint }}$ \\
\hline
\end{tabular}




\begin{tabular}{|c|c|c|}
\hline \multicolumn{2}{|c|}{ Statistic [min,max] } & Sample Mean, (SD) \\
\hline \multicolumn{2}{|c|}{ Total number of respondents (\#) } & 450 \\
\hline \multicolumn{2}{|c|}{ Age (years) $[18,65]$} & $37.43(13.90)$ \\
\hline \multicolumn{2}{|c|}{ Energy saving measures installed (\#) $[0,6]$} & $2.28(1.24)$ \\
\hline \multicolumn{2}{|c|}{ Environmentally friendly behavior index $[5,35])$} & $24.19(3.80)$ \\
\hline \multicolumn{2}{|c|}{ Charging inconvenience., 5-point Likert $[-2,2])$} & $0.0 \quad(1.13)$ \\
\hline \multicolumn{2}{|c|}{ Experience with solar-powered devices. (\#) $[0,8]$} & $1.72(1.33)$ \\
\hline \multicolumn{2}{|c|}{ Male $(\%)$} & 48.7 \\
\hline \multirow{6}{*}{ Household size } & 1 & $14.8 \%$ \\
\hline & 2 & $27.7 \%$ \\
\hline & 3 & $20.4 \%$ \\
\hline & 4 & $23.8 \%$ \\
\hline & 5 & $8.1 \%$ \\
\hline & $>5$ & $5.2 \%$ \\
\hline \multirow{7}{*}{$\begin{array}{l}\text { Monthly net } \\
\text { family income } \\
(€)\end{array}$} & $0-1,000$ & $2.8 \%$ \\
\hline & $1,001-2,000$ & $26.6 \%$ \\
\hline & $2,001-3,000$ & $23.5 \%$ \\
\hline & $3,001-4,000$ & $25.1 \%$ \\
\hline & $4,001-5,000$ & $14.7 \%$ \\
\hline & $5,001-6,000$ & $3.7 \%$ \\
\hline & $>6,000$ & $3.6 \%$ \\
\hline \multirow{5}{*}{ Education level } & Elementary & $2.3 \%$ \\
\hline & Secondary & $40.1 \%$ \\
\hline & College & $31.3 \%$ \\
\hline & University & $21.2 \%$ \\
\hline & Post-university & $5.1 \%$ \\
\hline \multirow{5}{*}{$\begin{array}{l}\text { Geographic } \\
\text { distribution }\end{array}$} & Antwerp & $22.7 \%$ \\
\hline & East Flanders & $15.5 \%$ \\
\hline & Flemish Brabant & $15.1 \%$ \\
\hline & Limburg & $33.9 \%$ \\
\hline & West Flanders & $12.8 \%$ \\
\hline
\end{tabular}




\begin{tabular}{|c|c|c|c|c|}
\hline \multirow[b]{2}{*}{$\begin{array}{l}\text { Main and interaction } \\
\text { effects }\end{array}$} & \multicolumn{2}{|c|}{ Mean } & \multicolumn{2}{|c|}{ Standard deviation } \\
\hline & Coef. & s.e. & Coef. & s.e. \\
\hline$\beta_{15 \%}$ & $-0.57 * * *$ & 0.12 & $0.78 * * *$ & 0.17 \\
\hline$\beta_{10 \%}$ & $-1.67 * * *$ & 0.15 & $1.53 * * *$ & 0.23 \\
\hline$\beta_{5 \%}$ & $-3.33 * * *$ & 0.28 & $2.66 * * *$ & 0.31 \\
\hline$\beta_{15 y}$ & 0.10 & 0.13 & $1.07 * * *$ & 0.15 \\
\hline$\beta_{10 y}$ & $-0.71 * * *$ & 0.15 & $1.35 * * *$ & 0.17 \\
\hline$\beta_{5 y}$ & $-2.93 * * *$ & 0.26 & $2.40 * * *$ & 0.25 \\
\hline$\beta_{u g}$ & $1.24 * * *$ & 0.22 & $1.00 * *$ & 0.39 \\
\hline$\beta_{n i}$ & $1.87 * * *$ & 0.28 & $1.69 * * *$ & 0.27 \\
\hline$\beta_{v n i}$ & $1.91 * * *$ & 0.26 & $1.69 * * *$ & 0.26 \\
\hline$\beta_{\text {pint }}$ & $0.39 * * *$ & 0.15 & $0.87 * * *$ & 0.29 \\
\hline$\beta_{\text {int }}$ & $1.65 * * *$ & 0.17 & $1.54 * * *$ & 0.45 \\
\hline$\beta_{\text {vint }}$ & $1.52 * * *$ & 0.16 & $1.48 * * *$ & 0.57 \\
\hline$\beta_{p r}$ & $-0.25 * * *$ & 0.03 & I & I \\
\hline$\beta_{1}$ & $-0.51 *$ & 0.30 & / & / \\
\hline$\beta_{2}$ & $-0.46^{*}$ & 0.26 & / & I \\
\hline$\beta_{3}$ & $-0.58 * *$ & 0.29 & / & / \\
\hline$\beta_{4}$ & $-0.66 * *$ & 0.28 & / & / \\
\hline$\beta_{5}$ & $0.59 * *$ & 0.24 & l & I \\
\hline$\beta_{6}$ & $0.49 * *$ & 0.23 & l & l \\
\hline$\beta_{7}$ & $0.63 * *$ & 0.29 & l & l \\
\hline Error component & 0 & (fixed) & $2.23 * * *$ & 0.24 \\
\hline & $\begin{array}{r}\text { Log-I } \\
\text { Pseudo } \mathrm{R}^{2} \\
\end{array}$ & $\begin{array}{l}\text { od }=-34 \\
=0.297 \\
037.5\end{array}$ & & \\
\hline
\end{tabular}


Table 5: Four segment LC model output

\begin{tabular}{|c|c|c|c|c|c|c|c|c|}
\hline \multirow{2}{*}{ Attributes } & \multicolumn{2}{|c|}{ Class $1(0.224)$} & \multicolumn{2}{|c|}{ Class $2(0.32)$} & \multicolumn{2}{|c|}{ Class 3 (0.256) } & \multicolumn{2}{|c|}{ Class 4 (0.199) } \\
\hline & Coef. & s.e. & Coef. & s.e. & Coef. & s.e. & Coef. & s.e. \\
\hline $\boldsymbol{\beta}_{15 \%}$ & $-0.47 * *$ & 0.20 & -0.13 & 0.15 & $-0.32 * *$ & 0.13 & $-1.02 * * *$ & 0.19 \\
\hline $\boldsymbol{\beta}_{10 \%}$ & $-0.97 * * *$ & 0.30 & $-0.37 * *$ & 0.18 & $-1.74 * * *$ & 0.22 & $-2.21 * * *$ & 0.30 \\
\hline $\boldsymbol{\beta}_{\mathbf{5} \%}$ & $-1.88 * * *$ & 0.37 & $-0.38 * *$ & 0.18 & $-4.13 * * *$ & 0.44 & $-3.18 * * *$ & 0.48 \\
\hline$\beta_{15 y}$ & -0.38 & 0.24 & $0.31 * *$ & 0.14 & $0.91 * * *$ & 0.21 & $-1.00 * * *$ & 0.22 \\
\hline$\beta_{10 y}$ & -0.17 & 0.19 & $-0.11-$ & 0.17 & -0.11 & 0.23 & $-2.15 * * *$ & 0.29 \\
\hline$\beta_{5 y}$ & $-0.83 * * *$ & 0.26 & $-0.49 *$ & 0.25 & $-2.46^{* * * *}$ & 0.28 & $-3.72 * * *$ & 0.47 \\
\hline$\beta_{u g}$ & $1.28 * * *$ & 0.45 & $0.30 * *$ & 0.15 & $1.23 * * *$ & 0.27 & 0.33 & 0.32 \\
\hline$\beta_{n i}$ & $3.87 * * *$ & 0.46 & $0.50 * * *$ & 0.18 & $1.64 * * *$ & 0.24 & $0.63 * *$ & 0.30 \\
\hline$\beta_{v n i}$ & $3.71 * * *$ & 0.44 & $0.51 * * *$ & 0.16 & $1.41 * * *$ & 0.23 & $0.58 *$ & 0.31 \\
\hline$\beta_{\text {pint }}$ & 0.19 & 0.20 & $0.49 * * *$ & 0.18 & -0.05 & 0.20 & 0.04 & 0.31 \\
\hline $\boldsymbol{\beta}_{\text {int }}$ & $1.08 * * *$ & 0.22 & $1.49 * * *$ & 0.17 & $0.93 * * *$ & 0.21 & $0.67 * *$ & 0.33 \\
\hline$\beta_{\text {vint }}$ & $1.21 * * *$ & 0.24 & $1.49 * * *$ & 0.18 & $0.76 * * *$ & 0.20 & $0.58 *$ & 0.30 \\
\hline$\beta_{p r}$ & $-0.23 * * *$ & 0.08 & $-0.09 * *$ & 0.05 & $-0.45 * * *$ & 0.07 & -0.12 & 0.11 \\
\hline \multicolumn{9}{|c|}{ Segment function: respondents' social and economic characteristics } \\
\hline Constant & -0.34 & 0.43 & 0.04 & 0.42 & 0.41 & 0.34 & 0 & (fixed) \\
\hline S energyaware & 0.24 & 0.38 & -0.54 & 0.39 & 0.12 & 0.35 & 0 & (fixed) \\
\hline$S_{\text {envaware }}$ & $-1.06^{* *}$ & 0.42 & 0.03 & 0.42 & -0.004 & 0.37 & 0 & (fixed) \\
\hline Simpatient & $1.25^{* * *}$ & 0.42 & 0.37 & 0.37 & 0.31 & 0.35 & 0 & (fixed) \\
\hline Sexperienced & -0.12 & 0.40 & 0.37 & 0.40 & -0.39 & 0.40 & 0 & (fixed) \\
\hline \multicolumn{9}{|c|}{$\begin{array}{c}\text { Log likelihood = }-3532.27 \\
\text { Pseudo-R }{ }^{2}(\text { adj })=0.274(0.260) \\
\text { AIC }=7198.5\end{array}$} \\
\hline
\end{tabular}




\begin{tabular}{|c|c|c|}
\hline & $\mathbf{W T P}(€ / \mathbf{W p})$ & $95 \% \mathrm{CI}$ \\
\hline $\boldsymbol{W T P} \boldsymbol{P}_{15 \%}$ & $-2.25 * * *$ & {$[-3.48 ;-1.02]$} \\
\hline $\boldsymbol{W T} \boldsymbol{P}_{10 \%}$ & $-6.58 * * *$ & {$[-13.43 ;-7.23]$} \\
\hline $\boldsymbol{W T P} \boldsymbol{P}_{\mathbf{5} \%}$ & $-14.02 * * *$ & {$[-18.15 ;-9.89]$} \\
\hline$W T P_{15 y}$ & 0.41 & {$[-0.64 ; 1.45]$} \\
\hline$W T P_{10 y}$ & $-2.80 * * *$ & {$[-4.09 ;-1.50]$} \\
\hline$W T P_{5 y}$ & $-10.33 * * *$ & {$[-13.43 ;-7.23]$} \\
\hline$W T P_{u g}$ & $4.10 * * *$ & {$[2.34 ; 5.87]$} \\
\hline$W T P_{n i}$ & $7.81 * * *$ & {$[5.43 ; 10.18]$} \\
\hline$W T P_{v n i}$ & $7.57 * * *$ & [5.18;9.96] \\
\hline$W T P_{\text {pint }}$ & $1.54 * *$ & {$[0.32 ; 2.75]$} \\
\hline$W T P_{i n t}$ & $6.52 * * *$ & {$[4.60 ; 8.44]$} \\
\hline$W T P_{\text {vint }}$ & $6.01 * * *$ & [3.93;8.09] \\
\hline
\end{tabular}

